\title{
Variation of stream metabolism along a tropical environmental gradient
}

\author{
Wesley A. SALTARELLI, ${ }^{*}$ Walter K. DODDS, ${ }^{2}$ Flavia TROMBONI,${ }^{3 \S}$ Maria do Carmo CALIJURI, ${ }^{1}$ \\ Vinicius NERES-LIMA, ${ }^{3}$ Carlos E. JORDÃO,${ }^{4}$ Julio C.P. PALHARES, ${ }^{4}$ Davi G.F. CUNHA ${ }^{1}$ \\ ${ }^{1}$ Departamento de Hidráulica e Saneamento, Escola de Engenharia de São Carlos, Universidade de São Paulo, Avenida Trabalhador \\ São-Carlense 400, CEP 13566-590 São Carlos, SP, Brazil; ${ }^{2}$ Division of Biology, Kansas State University, Manhattan, KS, USA; \\ ${ }^{3}$ Departamento de Ecologia, IBRAG, Universidade do Estado do Rio de Janeiro, RJ, Brazil; ${ }^{4}$ Empresa Brasileira de Pesquisa \\ Agropecuária, Embrapa Pecuária Sudeste, São Carlos, SP, Brazil \\ §Present address: Global Water Center and Biology Department, University of Nevada, Reno, NV, USA \\ *Corresponding author: wesley.saltarelli@gmail.com
}

\begin{abstract}
Stream metabolism is affected by both natural and human-induced processes. While metabolism has multiple implications for ecological processes, relatively little is known about how metabolic rates are influenced by land use in tropical streams. In this study, we assessed the metabolic characteristics and related environmental factors of six streams located in a transition area from Cerrado to Atlantic Forest (São Carlos/Brazil). Three streams were relatively preserved, while three were flowing through more agriculturally and/or urban impacted watersheds. Surface water samples were analyzed for biological and physico-chemical parameters as well as discharge and percentage of canopy cover. Metabolism was determined through the single-station method to estimate gross primary production (GPP), ecosystem respiration (ER) and net ecosystem production (NEP) with BAyesian Single-station Estimation (BASE). Nutrient concentrations tended to be higher in impacted versus preserved streams (e.g., average total phosphorus between 0.028 $0.042 \mathrm{mg} \mathrm{L}^{-1}$ and $0.009-0.038 \mathrm{mg} \mathrm{L}^{-1}$, respectively). Average canopy cover varied between 58 and $77 \%$, with no significant spatial or seasonal variation. All streams were net heterotrophic (ER exceeded GPP) in all sampling periods. GPP rates were always lower than $0.7 \mathrm{gO}_{2} \mathrm{~m}^{-2} \mathrm{~d}^{-1}$ in all streams and ER varied from 0.6 to $42.1 \mathrm{gO}_{2} \mathrm{~m}^{-2} \mathrm{~d}^{-1}$. Linear Mixed-Effect models showed that depth, discharge, velocity and total phosphorus are the most important predictors for GPP. For ER, depth, velocity and canopy cover are significant potential predictors. Canopy cover was the main light limiting factor and influenced stream metabolism. Our findings reinforced the concepts that shifts in the shading effect provided by vegetation (e.g., through deforestation) or changes in discharge (e.g., through land use conversion or water abstractions) can impact freshwater metabolism. Our study suggests that human activities in low latitude areas can alter tropical streams' water quality, ecosystem function, and the degree of riparian influence. Our data showed that tropical streams can be especially responsive to increases of organic matter inputs leading to high respiration rates and net heterotrophy, and this should be considered to support management and restoration efforts.
\end{abstract}

Key words: Ecosystem function; first-order streams; primary production; trophic state; functional indicators.

Received: November 2017. Accepted: April 2018.

\section{INTRODUCTION}

Stream metabolism, defined by the balance between organic matter produced via photosynthesis and consumed through aerobic respiration, is an important property of ecosystems, with significant influences on energy fluxes and ecosystem functioning (Fellows et al., 2006; Correa-González et al., 2014). The relative importance of Gross Primary Production (GPP) and Ecosystem Respiration (ER) defines the prevalence of either autotrophy or heterotrophy, affecting the role of the aquatic systems in carbon dynamics, nutrient cycling and dissolved oxygen production (Dodds and Cole, 2007). The metabolic activity in streams is regulated by factors such as light, flow regime, and seasonal variation of nutrient availability. It can be further affected by land use conversion and anthropogenic impacts, causing overall environmental degradation (e.g., eutrophication and biodiversity loss) (Dodds et al., 2013; Capps et al., 2016). Metabolism has multiple implications for ecological processes. It affects the nutritional quality of resources available for consumers in the food chains, and therefore secondary productivity (Boëchat et al., 2011). Metabolism also plays an important role in providing ecosystem services related to drinking water quality, pollution abatement and nutrient retention (Hall and Tank, 2003; Sobota et al., 2012). Nitrogen and phosphorus retention depends on the environmental concentrations, contribution of internal loads, and relative importance of different biogeochemical processes. Such retention can be altered by the anthropogenic influences on GPP and ER (Gücker and Pusch, 2006; Merseburger et al., 2011). Organic matter processing, which is directly linked with the self-depuration capacity of the water bodies, can co- 
vary with metabolism and depends on biotic (e.g., uptake) and abiotic (e.g., adsorption) processes (Tank et al., 2010).

Low-order streams are more numerous and greater in length, in comparison to higher order streams and rivers (Loiselle et al., 2016). Headwaters can be especially important for biodiversity (Meyer et al., 2007; Finn et al., 2011) and hotspots for biological processes such as degradation of leaf litter and other organic matter (Gessner et al., 2010; Casas et al., 2013; Longhi et al., 2016). However, most monitoring programs, especially in low-latitude areas, focus on larger waterbodies, and smaller-size streams remain often unmonitored (Loiselle et al., 2016). Low-order streams with significant canopy cover frequently have a prevalence of heterotrophic processes, due to inputs of allochthonous organic material (e.g., leaf decomposition) and less solar radiation available for photosynthesis (Marzolf et al., 1994).

Multiple and cumulative anthropogenic stressors (e.g., acidification, temperature and flow regime shifts, contamination, droughts and invasive species) (see Jackson et al., 2016) influence headwater streams (Bunn et al., 1999; Fellows et al., 2006; Young et al., 2008), including impacts to biological communities (Rasmussen et al., 2013), changes in flow dynamics and water temperature associated with global change (Taniwaki et al., 2017), and water quality, due to urban and agricultural land uses, in both riparian and whole watershed scales (Foley, 2005; Meyer et al., 2005; Tromboni and Dodds, 2017). Stream metabolism in altered sites can be influenced by shifts in water chemistry and characteristics of substrate and canopy cover, changes in land use and other anthropogenic disturbances (Mulholland et al., 2005). Lower GPP is frequently associated with increasing water turbidity (Hall et al., 2015) and population density in the catchments (Izagirre et al., 2008). Canopy deforestation can increase autochthonous primary production (Bleich et al., 2015). Autotrophic conditions can also be found under nutrient-enrichment conditions that stimulate benthic algae during day, and normally associated with high respiration rates during the night. This is commonly observed for urban catchments receiving effluent discharges (Halliday et al., 2015), eutrophic river segments with altered hydrology (Pinardi et al., 2011; Pinardi et al., 2014), or under other conditions of high organic matter supply (e.g., leaf inputs, organic content of the substrate) (Young and Huryn, 1999).

Metabolism is thus influenced by both natural and human-induced processes. Landscape (e.g., riparian vegetation) and stream restoration techniques can also affect metabolic rates (Roley et al., 2014; Burrell et al., 2014). To develop a biome-specific view of the main factors controlling lotic systems worldwide (Dodds et al., 2015), inter-biome, inter-regional comparisons of factors controlling stream metabolism are warranted (Mulholland et al., 2001; Bernot et al., 2010). Tropical areas have lower natural climate variability (Mora et al., 2013) when compared to their temperate counterparts, as well as higher absolute water temperatures and rainfall (Dai and Trenberth, 2002; Boulton et al., 2008). Faster chemical weathering (White et al., 1998), significant leaching of the surrounding areas, as well as greater inputs of solar radiation (depending on the canopy cover), are expected in tropical streams and might influence oxygen saturation and metabolism. However, there is still missing information about spatial and temporal factors related to stream metabolism in tropical and subtropical zones, especially in biomes like the Atlantic Rainforest and Cerrado biomes in Brazil (except see Tromboni et al., 2017).

The objective of this study was to estimate metabolic rates in tropical streams located in a transition area between Cerrado and Atlantic Forest biomes under pristine or impacted conditions. We investigated the correlations between environmental variables and stream metabolism to assess the role of land use and seasonality on GPP and ER. We hypothesized that the studied streams would be net heterotrophic, with the allochthonous contribution being predominant compared to the autochthonous production (Neres-Lima et al., 2017). We also hypothesized that GPP and ER would be greater in these tropical streams compared to temperate streams, because they receive higher solar irradiance (influencing GPP) and higher temperature (influencing ER). Finally, we expected GPP and ER to increase with anthropogenic modification in the watershed, as a consequence of both greater light availability and higher temperatures from the decreased shading effect due to riparian deforestation, and increased nutrient inputs.

\section{METHODS}

\section{Study area}

Six tropical first-order streams were selected for this study (Tab. 1 and Supplementary Material with a map), located in São Carlos and Brotas (São Paulo State, Southeastern Brazil) and with discharges always below $100 \mathrm{~L} \mathrm{~s}^{-1}$. These stream catchments had various degrees of disturbance (e.g., in relation to canopy cover, substrate and soil degradation) ranging from more preserved conditions (streams Espraiado, Fazzari, Broa) to altered sites impacted by urbanization and soil erosion due to rainwater discharge (stream Mineirinho), agriculture (stream Canchim) and sugarcane crops and fragmented riparian forest (stream Santa Maria). We assessed reach lengths between 33 and $110 \mathrm{~m}$ (Tab. 1), chosen to have a minimum travel time of around 20 minutes. There were negligible lateral inflows (i.e., increases in discharge from the upper to lower stations were mostly below 5\%). 
Total annual precipitation in the region is around 1500 $\mathrm{mm}$, with rainy summers (average generally $>150$ $\mathrm{mm} / \mathrm{month}$ ) and dry winters (averages $<70 \mathrm{~mm} / \mathrm{month}$ ). Air temperatures typically range from 17 to $23^{\circ} \mathrm{C}$. The riparian vegetation is mostly characterized by second growth vegetation typical of Cerrado (Brazilian Savannah) and its transition to Atlantic Rainforest. Streams are therefore shaded most time of the year, with a slightly increase in light availability in the dry season, due to the presence of some deciduous plant species.

\section{Field measurements}

Sampling campaigns were carried out in October $\left(14^{\text {th }}\right.$ to $\left.29^{\text {th }}\right)$ and December ( $1^{\text {st }}$ to $\left.16^{\text {th }}\right) 2015$ and February/March (23 $3^{\text {rd }}$ to $\left.9^{\text {th }}\right)$, May ( $3^{\text {rd }}$ to $\left.12^{\text {th }}\right)$, June/July ( $28^{\text {th }}$ to $\left.7^{\text {th }}\right)$ and August (9 $9^{\text {th }}$ to $\left.19^{\text {th }}\right) 2016$, to encompass natural variations of the climate conditions in the region (i.e., air temperatures and rainfall patterns). During those months, total monthly precipitation was $45,157,191,10$, 118 and $51 \mathrm{~mm}$ with average air temperatures of 24.0 , $23.6,23.9,22.9,16.5$ and $19.3^{\circ} \mathrm{C}$, respectively. The percentage of canopy cover was assessed during each sampling date with a spherical densiometer (concave model from Forestry Suppliers $\AA$, by Lemmon, 1956), as a proxy for the temporal variation in vegetation shading.

\section{Metabolism measurements}

The reaeration coefficients $\left(\mathrm{k}_{\mathrm{O} 2}\right)$ of each stream were directly estimated at base flow and at least once across the sampling periods. Mean velocity and discharge were estimated through the conservative tracer method, with a $\mathrm{NaCl}$ pulse and a conductivity meter (Hanna ${ }^{\circledR}$ 9828, Hanna Instruments, Limena, Italy) measuring downstream from the release point (Webster and Valett, 2006). To estimate the $\mathrm{k}_{\mathrm{O} 2}$ values, the same solute tracer was associated with a gas tracer $\left(\mathrm{SF}_{6}\right)$ in a continuous release (constant rates with a FMI Lab Pump - model
QBG). After we established plateau conditions for conductivity throughout the reaches, samples for $\mathrm{SF}_{6}$ were collected in six transects, with glass vials previously rinsed and stream water was collected to avoid air bubbles. $\mathrm{SF}_{6}$ concentrations were estimated with a gas chromatography (Thermo Scientific $\left.{ }^{\circledR}\right)$ at a laboratory at the Brazilian Agricultural Research Corporation (Embrapa Pecuária Sudeste, Fazenda Canchim, São Carlos). We measured the gas loss along the reach length stations and use one-dimensional advection-dispersion equation for the estimation of the SF6 reaeration coefficient (Benson et al., 2014):

$C_{x}=C_{0} e^{-(k / U) x}$

where: $\mathrm{U}$ is the mean stream velocity; $\mathrm{x}$ is the distance downstream of release; $\mathrm{C}_{\mathrm{x}}$ is the concentration of gas tracer at the point $\mathrm{x} ; \mathrm{C}_{0}$ is the initial concentration of gas tracer at the injection point $(\mathrm{x}=0)$. The $\mathrm{k}_{\mathrm{O} 2}$ was determined through a conversion factor $\left(\mathrm{k}_{\mathrm{O} 2}=1.38 \times \mathrm{k}_{\mathrm{SF} 6}\right)$ provided by Canale et al. (1995), and the $\mathrm{k}_{\mathrm{O} 2}$ was normalized for $20^{\circ} \mathrm{C}$. The $\mathrm{k}_{\mathrm{SF} 6}$ values were determined at least once across the sampling periods and we recognize discharge variations can cause variation in $\mathrm{k}_{\mathrm{O} 2}$ values and therefore uncertainty in metabolic rates estimates. Average width values were measured in each sampling date in six transects in all the reaches (the total length from each reach, Tab. 1, was divided into six parts). The average depth was calculated from velocity and width.

Sensors with data loggers were deployed to monitor changes in PAR (Onset-HOBO ${ }^{\circledR}$ UA-002-64, Onset Computer Corporation, Bourne, MA, USA), barometric pressure (Onset-HOBO $\left.{ }^{\circledR} \mathrm{U} 20 \mathrm{~L}-04\right)$, dissolved oxygen (DO) and temperature (Onset-HOBO ${ }^{\circledR}$ U26-001) every ten minutes for two days. Probes were calibrated prior to deployment, and post deployment calibrations were used to correct drift in the data provided by the sensors. Metabolism was measured at relatively low flows (not

Tab. 1. Information about the studied first-order streams, including their names, codes, drainage areas, reach lengths used for metabolism estimations and geographic coordinates (latitude/longitude). The acronyms for the streams bring information about their condition, where (P) stands for preserved and (I) stands for impacted sites.

\begin{tabular}{|c|c|c|c|c|}
\hline Stream & Acronym & $\begin{array}{c}\text { Drainage area }\left(\mathrm{km}^{2}\right) \\
\text { of the reach }\end{array}$ & Reach length (m) & Geographic coordinates \\
\hline Espraiado & $\operatorname{ESP}(\mathrm{P})$ & 2.49 & 110 & $\mathrm{~S} 21^{\circ} 58.831^{\prime} \mathrm{W} 47^{\circ} 52.418^{\prime}$ \\
\hline Fazzari & FAZ (P) & 0.69 & 33 & $\mathrm{~S} 21^{\circ} 58.134^{\prime} \mathrm{W} 47^{\circ} 53.138^{\prime}$ \\
\hline Broa & $\mathrm{BRO}(\mathrm{P})$ & 2.68 & 68 & $\mathrm{~S} 22^{\circ} 11.682^{\prime} \mathrm{W} 47^{\circ} 53.930^{\prime}$ \\
\hline Canchim & CAN (I) & 1.17 & 70 & $\mathrm{~S} 21^{\circ} 58.012^{\prime} \mathrm{W} 47^{\circ} 50.562^{\prime}$ \\
\hline Mineirinho & MIN (I) & 0.82 & 98 & $\mathrm{~S} 22^{\circ} 0.213^{\prime} \mathrm{W} 47^{\circ} 55.680^{\prime}$ \\
\hline Santa Maria & SMA (I) & 6.24 & 75 & $\mathrm{~S} 22^{\circ} 2.672^{\prime} \mathrm{W} 47^{\circ} 58.083^{\prime}$ \\
\hline
\end{tabular}


during or soon after storms) so aeration estimates, also measured at base flow, would be comparable at times when we were not able to directly measure aeration.

\section{Metabolism modeling}

Metabolism was determined through the single-station method (Odum, 1956; Bott, 2006), and the rates of GPP were estimated from the rates of ER and NEP:

$\mathrm{GPP}=\mathrm{ER}+\mathrm{NEP}$

The rates of ER and NEP were determined through the BAyesian Single-station Estimation (BASE v2.0, updated in July 2016), model proposed by Grace et al., (2015) with measured data of Photosynthetically Active Radiation (PAR), barometric pressure, dissolved oxygen, temperature and reaeration coefficient $\left(\mathrm{k}_{\mathrm{O} 2}\right)$. A twoparameter model was used (because $\mathrm{k}_{\mathrm{O} 2}$ was measured and fixed) and, following the default of BASE, 20,000 iterations were performed with 10,000 burn-in and theta (constant for temperature dependence, by Van't HoffArrhenius equation) fixed (1.07177). BASE used the model of diurnal regression, developed by Odum (1956), with the diel variations in stream $\mathrm{O}_{2}$ concentrations to calculate GPP and ER. The model considered the reaeration rate measured and water temperature.

$\frac{d C}{d t}=G P P-E R+k_{O 2}(C s-C)$

where $\mathrm{C}$ is $\mathrm{O}_{2}$ concentrations ( $\mathrm{mg} \mathrm{L}^{-1}$ ), Cs is saturating $\mathrm{O}_{2}$ concentration $\left(\mathrm{mg} \mathrm{L}^{-1}\right), \mathrm{k}_{\mathrm{O} 2}$ is reaeration coefficient $\left(\mathrm{d}^{-1}\right)$. The detection limit of the GPP and ER rates were assumed as $0.1 \mathrm{mgO}_{2} \mathrm{~L}^{-1} \mathrm{~d}^{-1}$. Such metabolic rates estimated by the model in $\mathrm{mgO}_{2} \mathrm{~L}^{-1} \mathrm{~d}^{-1}$ were converted to $\mathrm{gO}_{2} \mathrm{~m}^{-2} \mathrm{~d}^{-1}$ using the mean depth $(\mathrm{m})$ of each site as calculated from average velocity and average width.

\section{Water and substrate variables}

Surface water samples were analyzed for the following parameters according to APHA (2012) methods: conductivity, $\mathrm{pH}$, turbidity, total suspended solids (and their organic and inorganic fractions), total phosphorus (TP), soluble reactive phosphorus (SRP), nitrate $\left(\mathrm{NO}_{3}{ }^{-}\right)$, nitrite $\left(\mathrm{NO}_{2}^{-}\right)$, total Kjeldahl nitrogen (TKN), dissolved organic (DOC) and inorganic carbon (DIC). Substrate characterization (e.g., sand, silt, rock, roots or leaves composition) was performed across the study reaches with 20 transects with 5 points each, or 10 transects with 10 points each, if average widths were lower or higher than $1 \mathrm{~m}$, respectively. We sampled six replicates per stream of the most dominant substrata (making up $80 \%$ or more of the total). Chlorophyll-a was determined following hot ethanol extraction (Sartory and Grobbelaar, 1984), followed by the calculation of weighted chlorophyll averages ( $\mathrm{mg} \mathrm{m}^{-2}$ ), according to the relative contribution of each substratum.

\section{Statistical analyses}

To assess statistically significant differences in all studied variables regarding season (i.e., the temporal effect) and site condition (i.e., merging all data for pristine versus all data for impacted sites), as well as their interaction (temporal and site factors), was used a Mixed Effects Model (MEM) with streams as a random variable and impact and campaign (six campaigns) as fixed factors. Was used the lme4 packages (Bates et al. 2014) in R software (R Core Team, 2015). All residuals were analyzed. The $p$ values with Satterthwaite approximation for denominator degrees of freedom were obtained using the lmerTest R package (Kuznetsova et al. 2016). All data were previously normalized (as $\ln +1$ ) before the statistical analyses.

Linear Mixed-Effects models were then applied to explain variations in GPP and ER, with stream as a random variable, time as an independent factor and the physico-chemical variables as fixed effects. Models' selection was based on the Akaike's Information Criterion (AIC). The P-values, with Satterthwaite approximation for denominator degrees of freedom, were obtained using the lmerTest R package (Kuznetsova et al. 2016), for the independent variables of the models. All analyses were conducted using the R software (R Core Team, 2015).

\section{RESULTS}

The study streams presented a range of water quality conditions in relation to the examined physical and chemical variables. Average water temperature, turbidity and TSS in the streams ranged between $18.0-21.7^{\circ} \mathrm{C}, 1-$ 49 NTU and 1-7 $\mathrm{mg} \mathrm{L}^{-1}$ respectively (Tab. 2), with no significant impact difference for the former variables $(\mathrm{P}>0.05$, Tab. 3). Average $\mathrm{pH}$ (6.4-6.7) and electric conductivity $\left(29-39 \mu \mathrm{S} \mathrm{cm}^{-1}\right)$ were greater in the impacted sites $(\mathrm{P}<0.05$, Tab. 3). $\mathrm{ESP}(\mathrm{P}), \mathrm{FAZ}(\mathrm{P}), \mathrm{BRO}(\mathrm{P})$ and CAN(I) showed predominance of organic fraction of TSS: $53,54,81$ and $60 \%$, respectively, while MIN(I) and SMA(I) presented predominance of inorganic fraction, with 69 and 52\% respectively.

Average DIC concentrations varied between 0.6 to 2.2 $\mathrm{mg} \mathrm{L}^{-1}$ in preserved sites and 2.2-3.0 $\mathrm{mg} \mathrm{L}^{-1}$ in impacted (Tab. 2), with significant temporal difference $(\mathrm{P}<0.05$, Tab. 3). The DOC concentrations were similar across streams with the only exception of the stream SMA(I) that presented a higher average of DOC (7.1 $\left.\mathrm{mg} \mathrm{L}^{-1}\right)$ (Tab. 2). $\mathrm{ESP}(\mathrm{P}), \quad \mathrm{FAZ}(\mathrm{P}), \quad \mathrm{BRO}(\mathrm{P})$ and $\mathrm{SMA}(\mathrm{I})$ showed 
predominance of organic carbon (OC): 63, 62, 87\% and $75 \%$, respectively, while CAN(I) and MIN(I) presented 57 and $52 \%$, respectively, of inorganic carbon (IC).

Average canopy cover varied between 58 and $77 \%$ (Tab. 2), with no significant temporal, site or temporal*site (interaction) variation (all $\mathrm{P}>0.500$ ) (Tab. 3). Average sestonic and benthic chlorophyll varied between 0.6-4.6 $\mu \mathrm{g}$ $\mathrm{L}^{-1}$ and 6.6-32.5 $\mathrm{mg} \mathrm{m}^{-2}$, respectively (Tab. 2), but just sestonic chlorophyll show defined patterns across impacted versus preserved streams and temporal effect $(\mathrm{P}<0.05, \mathrm{Tab}$. $3)$. The dominant substrata in the streams were sand [ESP(P), BRO(P), MIN(I)], rocks [CAN(I), SMA(I)] and leaves $[\mathrm{FAZ}(\mathrm{P})]$ (Tab. 2).

Average total phosphorus (TP) concentrations varied in impacted from 0.028 to $0.042 \mathrm{mg} \mathrm{L}^{-1}$ and in preserved streams from 0.009 to $0.038 \mathrm{mg} \mathrm{L}^{-1}$, with no significant impact and temporal differences $(\mathrm{P}>0.05$, Tab. 3) (Fig. 1A). The streams SMA(I) and BRO(P) had the lowest values of soluble reactive phosphorus but all other sites had similar concentrations (averages from 0.004 to 0.015 $\mathrm{mg} \mathrm{L}^{-1}$, Fig. 1B), and there was no difference across impacted versus pristine sites ( $\mathrm{P}>0.05$, Tab. 3 ). There were significant temporal differences in average nitrogen concentrations in the nitrogen forms $(\mathrm{P}<0.05$, Tab. 3$)$, but there were no significant differences between streams.

Streams presented daily variations in DO concentrations (see Supplementary Material for detailed dissolved oxygen plots) from 6.0 to $9.0 \mathrm{mg} \mathrm{L}^{-1}$ in $\mathrm{BRO}(\mathrm{P}), \mathrm{CAN}(\mathrm{I}), \mathrm{MIN}(\mathrm{I})$ and SMA(I), from 3.5 to $7.5 \mathrm{mg} \mathrm{L}^{-1}$ in $\operatorname{ESP}(\mathrm{P})$ and from 1.5 to $6.0 \mathrm{mg} \mathrm{L}^{-1}$ in $\mathrm{FAZ}(\mathrm{P})$. The stream $\mathrm{BRO}(\mathrm{P})$ had the lowest reaeration coefficient $\left(\mathrm{k}_{\mathrm{O} 2}, \sim 20 \mathrm{~d}^{-1}\right)$, followed by $\operatorname{ESP}(\mathrm{P})$ $\left(\sim 24 \mathrm{~d}^{-1}\right), \operatorname{FAZ}(\mathrm{P})\left(\sim 41 \mathrm{~d}^{-1}\right), \operatorname{CAN}(\mathrm{I})\left(\sim 99 \mathrm{~d}^{-1}\right), \operatorname{MIN}(\mathrm{I})$ $\left(\sim 122 \mathrm{~d}^{-1}\right)$ and SMA(I) $\left(\sim 274 \mathrm{~d}^{-1}\right)$ (Tab. 2$)$.

Gross primary production rates were always lower than $0.7 \mathrm{gO}_{2} \mathrm{~m}^{-2} \mathrm{~d}^{-1}$ in all streams. The ESP(P) stream had the greatest apparent GPP rates $\left(0.1-0.7 \mathrm{gO}_{2} \mathrm{~m}^{-2} \mathrm{~d}^{-1}\right)$ and MIN(I) and SMA(I) had the lowest (0.1 and $<0.1-0.1 \mathrm{gO}_{2}$ $\mathrm{m}^{-2} \mathrm{~d}^{-1}$, respectively) (Tab. 4). Ecosystem respiration varied between 0.6 and $42.1 \mathrm{gO}_{2} \mathrm{~m}^{-2} \mathrm{~d}^{-1}$ in all the streams, with rates lower in impacted streams $(\mathrm{P}<0.05$, Tab. 3$)$.

Tab. 2. Characterization of the study streams [Espraiado - ESP(P), Fazzari - FAZ(P), Broa - BRO(P), Canchim - CAN(I), Mineirinho - MIN(I) and Santa Maria - SMA(I)] regarding hydrological, water, substrate variables as well as canopy vegetation: discharge (Q), water velocity $(\mathrm{Vel})$, reaeration coefficient $\left(\mathrm{k}_{\mathrm{O} 2}\right)$ for $20^{\circ} \mathrm{C}$, wetted width, water temperature $(\mathrm{T}), \mathrm{pH}$, conductivity, total suspended solids (TSS), turbidity, dissolved organic carbon (DOC), dissolved inorganic carbon (DIC), canopy cover, sestonic and benthic chlorophyll (Chla) and relative importance of different materials (sand, silt, leaf, bark, root and rock) in the substrate. Averages \pm Standard Deviations are shown for each case (except for the substrate composition), considering six sampling periods (October and December 2015 and February, April, June and August 2016).

\begin{tabular}{|c|c|c|c|c|c|c|}
\hline \multirow[t]{2}{*}{ Variables } & \multicolumn{3}{|c|}{ Preserved sites } & \multicolumn{3}{|c|}{ Impacted sites } \\
\hline & $\operatorname{ESP}(\mathbf{P})$ & FAZ(P) & $\mathrm{BRO}(\mathrm{P})$ & CAN(I) & MIN(I) & SMA(I) \\
\hline $\mathrm{Q}\left(\mathrm{L} \mathrm{s}^{-1}\right)$ & $10.5 \pm 3.9$ & $2.2 \pm 2.1$ & $18.8 \pm 7.0$ & $4.1 \pm 1.3$ & $5.5 \pm 1.5$ & $69.0 \pm 24.1$ \\
\hline $\operatorname{Vel}\left(\mathrm{m} \mathrm{s}^{-1}\right)$ & $0.05 \pm 0.03$ & $0.03 \pm 0.03$ & $0.06 \pm 0.05$ & $0.08 \pm 0.03$ & $0.09 \pm 0.02$ & $0.22 \pm 0.07$ \\
\hline $\mathrm{k}_{\mathrm{O} 2}\left(\mathrm{~d}^{-1}\right)$ & $\sim 24$ & $\sim 41$ & $\sim 20$ & $\sim 99$ & $\sim 122$ & $\sim 274$ \\
\hline Wetted width (m) & 0.6 & 1.3 & 0.8 & 1.2 & 1.2 & 1.4 \\
\hline $\mathrm{T}\left({ }^{\circ} \mathrm{C}\right)$ & $18.0 \pm 2.7$ & $19.6 \pm 1.5$ & $19.0 \pm 2.5$ & $19.4 \pm 1.8$ & $20.0 \pm 2.5$ & $21.7 \pm 3.5$ \\
\hline $\mathrm{pH}$ & $5.6 \pm 0.2$ & $5.4 \pm 0.1$ & $4.6 \pm 0.3$ & $6.4 \pm 0.1$ & $6.6 \pm 0.2$ & $6.7 \pm 0.2$ \\
\hline Conductivity $\left(\mu \mathrm{S} \mathrm{cm}^{-1}\right)$ & $14 \pm 6$ & $12 \pm 6$ & $8 \pm 2$ & $29 \pm 3$ & $29 \pm 6$ & $39 \pm 4$ \\
\hline TSS $\left(\mathrm{mg} \mathrm{L}^{-1}\right)$ & $5 \pm 3$ & $4 \pm 1$ & $1 \pm 1$ & $6 \pm 6$ & $7 \pm 5$ & $4 \pm 1$ \\
\hline Turbidity (NTU) & $7 \pm 4$ & $6 \pm 2$ & $1 \pm 1$ & $14 \pm 7$ & $49 \pm 60$ & $9 \pm 3$ \\
\hline $\mathrm{DOC}\left(\mathrm{mg} \mathrm{L}^{-1}\right)$ & $3.8 \pm 3.1$ & $3.0 \pm 1.4$ & $3.7 \pm 4.0$ & $2.3 \pm 1.2$ & $2.0 \pm 0.4$ & $7.1 \pm 9.4$ \\
\hline $\mathrm{DIC}\left(\mathrm{mg} \mathrm{L}^{-1}\right)$ & $2.2 \pm 0.5$ & $1.9 \pm 0.7$ & $0.6 \pm 0.2$ & $3.0 \pm 0.4$ & $2.2 \pm 0.8$ & $2.4 \pm 0.3$ \\
\hline Canopy cover $(\%)$ & $72 \pm 5$ & $77 \pm 4$ & $66 \pm 16$ & $77 \pm 5$ & $74 \pm 2$ & $58 \pm 10$ \\
\hline Sestonic Chla $\left(\mu \mathrm{g} \mathrm{L}^{-1}\right)$ & $1.1 \pm 1.5$ & $0.6 \pm 1.5$ & $1.2 \pm 1.9$ & $3.9 \pm 6.7$ & $4.6 \pm 6.8$ & $3.2 \pm 3.7$ \\
\hline Benthic Chla (mg m$\left.{ }^{-2}\right)$ & $6.6 \pm 3.7$ & $11.6 \pm 5.2$ & $14.4 \pm 5.9$ & $32.5 \pm 14.1$ & $14.3 \pm 7.4$ & $7.4 \pm 5.0$ \\
\hline Sand (\%) in substrate & 31 & $*$ & 44 & 28 & 69 & 6 \\
\hline Silt (\%) in substrate & 21 & 14 & 29 & 18 & $*$ & $*$ \\
\hline Leaf $(\%)$ in substrate & 14 & 51 & 6 & $*$ & $*$ & $*$ \\
\hline Bark (\%) in substrate & 6 & 9 & 1 & $*$ & $*$ & $*$ \\
\hline Root (\%) in substrate & 28 & 26 & 20 & $*$ & $*$ & $*$ \\
\hline Rock (\%) in substrate & $*$ & $*$ & $*$ & 54 & 31 & 94 \\
\hline
\end{tabular}

*Below $0.5 \%$. 
ESP $(\mathrm{P})$ and FAZ $(\mathrm{P})$ presented the highest values of ER varying from 10.4 to 42.1 and from 2.7 to $41.3 \mathrm{gO}_{2} \mathrm{~m}^{-2}$ $\mathrm{d}^{-1}$, respectively (Tab. 4). NEP rates were always lower than $-0.5 \mathrm{gO}_{2} \mathrm{~m}^{-2} \mathrm{~d}^{-1}$ in all streams and showed that streams were heterotrophic (respiration exceeded gross primary production) in all sampling periods (Tab. 4).

NEP, ER and GPP showed significant variations across impacted versus preserved streams $(\mathrm{P}<0.05$, Tab. 3$)$ in relation to tested factors. Linear Mixed-Effect models (Tab. 5) showed that depth, discharge, velocity and total phosphorus were the most important predictors for GPP $(\mathrm{P}<0.05, \mathrm{AIC}=-75.43$ and -77.39 , Tab. 5). ER was mostly driven by depth, velocity, and canopy cover $(\mathrm{P}<0.05$, AIC $=59.89$ and 60.74).

\section{DISCUSSION}

All streams were heterotrophic during the entire year of the experiment, presenting high ER and low GPP rates compared to most other studies (see Bernot et al., 2010 and Hall and Beaulieu, 2013 for a comprehensive comparison). While there was no temporal variation on canopy cover, the riparian vegetation was a significant determinant of metabolism, not only by reducing solar radiation, but also by contributing with allochthonous organic material and determining different substrata characteristics. These two factors probably caused increases in ER and reduced GPP by light limitation. Also, total suspended solids can attenuate light affecting photosynthesis, as pointed by Lewis (2008) and observed by Young and Huryn (1996). However, in our study total suspend solids and turbidity were not correlated with GPP, probably because the streams are shallow and already light limited by canopy cover.

We note in the pristine/forested sites the possibility that apparent GPP rates may be an artifact of tree root respiration and diurnal patterns of evapotranspiration. This was reported by Dodds et al. (2017) in the Espraiado stream, ESP(P), where the authors measured the root

Tab. 3. Summary of mixed effects model results considering all studied variables $(n=36)$ and impact effects (land use types: impacted versus pristine sites), temporal effects (seasonality) and their interaction. Streams were set up as random factor. Significant effects at $\mathrm{P}<0.05$ are in bold.

\begin{tabular}{|c|c|c|c|}
\hline Variable & Impact effect & Temporal effect & $\begin{array}{c}\text { Interaction } \\
\text { (impact"temporal) effect }\end{array}$ \\
\hline Temperature & $\mathrm{P}=0.16$ & $\mathbf{P}<0.05$ & $P<0.05$ \\
\hline $\mathrm{pH}$ & $P<0.05$ & $\mathbf{P}<0.05$ & $\mathrm{P}=0.39$ \\
\hline Turbidity & $\mathrm{P}=0.10$ & $\mathrm{P}=0.10$ & $\mathrm{P}=0.65$ \\
\hline Dissolved oxygen & $\mathrm{P}=0.14$ & $\mathbf{P}<0.05$ & $\mathrm{P}=0.08$ \\
\hline Electric conductivity & $P<0.05$ & $\mathrm{P}=0.16$ & $\mathrm{P}=0.86$ \\
\hline Total suspended solids & $\mathrm{P}=0.28$ & $\mathrm{P}=0.17$ & $\mathrm{P}=0.33$ \\
\hline Inorganic suspended solids & $\mathrm{P}=0.20$ & $\mathrm{P}=0.60$ & $\mathrm{P}=0.18$ \\
\hline Organic suspended solids & 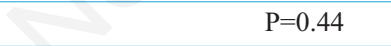 & $P<0.05$ & $\mathrm{P}=0.43$ \\
\hline Total nitrogen & $\mathrm{P}=0.69$ & $P<0.05$ & $\mathrm{P}=0.57$ \\
\hline Total Kjeldahl nitrogen & $\mathrm{P}=0.30$ & $\mathbf{P}<0.05$ & $\mathrm{P}=0.60$ \\
\hline Nitrate & $\mathrm{P}=0.41$ & $\mathbf{P}<0.05$ & $\mathrm{P}=0.29$ \\
\hline Nitrite & $\mathrm{P}=0.68$ & $P<0.05$ & $\mathrm{P}=0.22$ \\
\hline Total phosphorus & $\mathrm{P}=0.24$ & $\mathrm{P}=0.07$ & $\mathrm{P}=0.60$ \\
\hline Soluble reactive phosphorus & $\mathrm{P}=0.94$ & $\mathrm{P}<0.05$ & $P<0.05$ \\
\hline Dissolved inorganic carbon & $\mathrm{P}=0.18$ & $P<0.05$ & $\mathrm{P}=0.70$ \\
\hline Dissolved organic carbon & $\mathrm{P}=0.46$ & $\mathbf{P}<0.05$ & $\mathrm{P}=0.22$ \\
\hline Seston chlorophyll & $\mathbf{P}<0.05$ & $P<0.05$ & $\mathrm{P}=0.20$ \\
\hline Benthic chlorophyll & $\mathrm{P}=0.54$ & $\mathrm{P}=0.85$ & $\mathrm{P}=0.07$ \\
\hline Canopy cover & $\mathrm{P}=0.78$ & $\mathrm{P}=0.23$ & $\mathrm{P}=0.39$ \\
\hline Discharge & $\mathrm{P}=0.69$ & $P<0.05$ & $\mathrm{P}=0.33$ \\
\hline Velocity & $\mathrm{P}=0.13$ & $\mathbf{P}<0.05$ & $\mathrm{P}=0.30$ \\
\hline Gross primary production & $P<0.05$ & $\mathrm{P}=0.18$ & $\mathrm{P}=0.20$ \\
\hline Ecosystem respiration & $P<0.05$ & $\mathrm{P}=0.63$ & $\mathrm{P}=0.22$ \\
\hline Net ecosystem production & $\mathbf{P}<0.05$ & $\mathrm{P}=0.64$ & $\mathrm{P}=0.22$ \\
\hline
\end{tabular}


activity directly as it contributes to water DO concentration along the day/night cycle. During active transpiration in day, the trees remove low DO water, increasing DO concentrations observed in the stream channel. At night, the water is not moved up the plant vascular system and DO concentrations drop. This produced a DO pattern similar to that observed for the photosynthesis occurring in streams, with more DO concentration in the day time and reduced during the night. We were not able to directly measure root respiration in our study.

Average stream velocity presented a significant negative effect on GPP as noted also by other studies. Hydrological characteristics, such as discharge and average velocity, in fact can produce a temporal effect on the metabolism of streams, due to the scouring of stream biofilms (Hall, 2016). While we sampled all streams at base flow, stream average velocity was considered as an indicator that links to the seasonality of the study area (i.e., rainy summers and dry winters, see Saltarelli, 2017) and therefore related to abrasion and disturbance of biofilms. Stated differently, although our measurements were made at base flow, those made in the rainy period were more likely to have been made on biofilms subject to recent high flow events. Current velocity can significantly influence the architecture and temporal dynamics of natural biofilms (Battin et al., 2003) and thus aquatic metabolism. Discharge effects were also reported by Uehlinger et al. (2003), in experiments carried out in the Rio Spol (Swiss Alpes), located downstream of a reservoir. GPP was reduced by $64 \%$ and ER by $36 \%$ after flooding, and they were related to periphyton biomass reduction. On the other hand, Acuña et al. (2004) related the increase in GPP with an increase in discharge in a Spanish stream. In that case authors explained that discharge removed organic matter present in the periphyton, providing more light availability for the algal community.

The increase in phosphorus and nitrogen, essential for
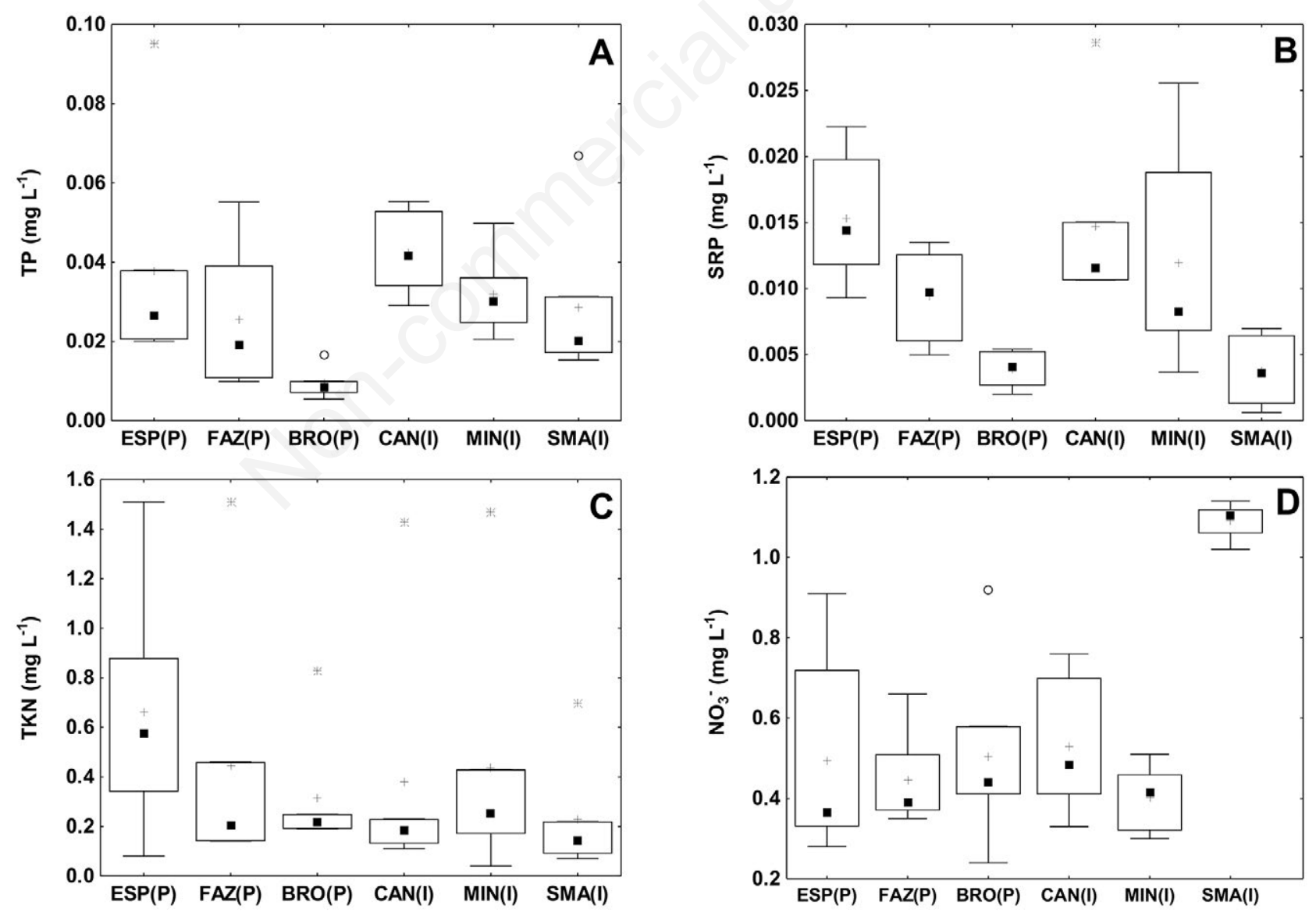

Fig. 1. Phosphorus and nitrogen concentrations across the studied streams [Espraiado - ESP(P), Fazzari - FAZ(P), Broa - BRO(P), Canchim - CAN(I), Mineirinho - MIN(I) and Santa Maria - SMA(I)]: A) total phosphorus (TP); B) soluble reactive phosphorus (SRP); C) total Kjeldahl

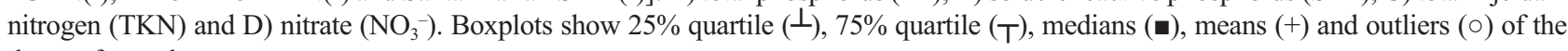
dataset for each stream. 
algal and macrophyte growth, can also affect metabolic rates (Dodds, 2007). In our study, the relationships between metabolic rates and nutrients, especially phosphorus, were suggested by the Linear Mixed-Effect models (Tab. 5). However, there is still limited evidence on the relationships between nutrient availability and algal biomass accrual, especially for non-experimental studies (Bernhardt et al., 2018). These authors argued that anthropogenic impacts on streams (e.g., surface runoff or wastewater inputs) bring a myriad of changes not only in nutrient supply, but also in light availability and other disturbances, and this makes it more difficult to assess the effects on each individual factor on stream metabolism. In tropical streams impacted by agriculture, SRP concentrations $\left(7.2 \mu \mathrm{g} \mathrm{L}^{-1}\right)$ were found to be related to higher GPP as in another study carried out in the Cerrado biome (Gücker et al., 2009). GPP also increased in a temperate river as a response to effluents from a wastewater treatment plant probably as a result of mixed effects from such effluents (Aristi et al., 2015). Silva-Junior (2016) summarized some metabolic responses across different biomes as a response of different land use stress.

Apparently, light and total phosphorus influenced GPP, as expected but depth and discharge were also important. We suspect this is not related to stimulation of respiration by primary producers, because ER rates were so much greater than GPP in most of our streams. Bott et al. (2006) reported that in Muscoot stream (New York), average nutrient concentrations were high (TN: $1.6 \mathrm{mg} \mathrm{L}^{-1}$ and TP: $\left.0.04 \mathrm{mg} \mathrm{L}^{-1}\right)$, and GPP was low $\left(0.4 \mathrm{gO}_{2} \mathrm{~m}^{-2} \mathrm{~d}^{-1}\right)$, suggesting light limited GPP and not nutrients. Bernot et

Tab. 4. Average temperature $\left({ }^{\circ} \mathrm{C}\right)$, DO maximum amplitude $\left(\mathrm{mg} \mathrm{L}^{-1}\right)$ and Net ecosystem production (NEP), Ecosystem respiration (ER) and Gross primary production (GPP) rates $\left(\mathrm{gO}_{2} \mathrm{~m}^{-2} \mathrm{~d}^{-1}\right)$ in the studied streams from October de 2015 to August 2016.

\begin{tabular}{|c|c|c|c|c|c|c|c|}
\hline & & Date & $\mathrm{T}\left({ }^{\circ} \mathrm{C}\right)$ & $\begin{array}{c}\Delta \mathrm{DO} \\
\left(\mathrm{mg} \mathrm{L}^{-1}\right)\end{array}$ & $\begin{array}{c}\text { GPP } \\
\left(\mathrm{gO}_{2} \mathrm{~m}^{-2} \mathrm{~d}^{-1}\right)\end{array}$ & $\begin{array}{c}\text { ER } \\
\left(\mathrm{gO}_{2} \mathrm{~m}^{-2} \mathrm{~d}^{-1}\right)\end{array}$ & $\begin{array}{c}\text { NEP } \\
\left(\mathrm{gO}_{2} \mathrm{~m}^{-2} \mathrm{~d}^{-1}\right)\end{array}$ \\
\hline \multirow[t]{3}{*}{ Preserved sites } & $\operatorname{ESP}(\mathrm{P})$ & $\begin{array}{c}\text { Oct/15 } \\
\text { Dec/15 } \\
\text { Feb/16 } \\
\text { Apr/16 } \\
\text { Jun/16 } \\
\text { Aug/16 }\end{array}$ & $\begin{array}{l}19.8 \\
20.9 \\
21.3 \\
16.4 \\
16.9 \\
17.3\end{array}$ & $\begin{array}{l}0.8 \\
0.5 \\
0.3 \\
0.6 \\
0.4 \\
0.5\end{array}$ & $\begin{array}{l}0.2 \pm 0.1 \\
0.7 \pm 0.1 \\
0.1 \pm 0.0 \\
0.1 \pm 0.0 \\
0.1 \pm 0.0 \\
0.2 \pm 0.0\end{array}$ & $\begin{array}{l}39.0 \pm 0.1 \\
42.1 \pm 0.1 \\
10.4 \pm 0.0 \\
13.6 \pm 0.0 \\
14.0 \pm 0.0 \\
23.5 \pm 0.0\end{array}$ & $\begin{array}{l}-38.8 \\
-41.4 \\
-10.3 \\
-13.5 \\
-13.9 \\
-23.3\end{array}$ \\
\hline & $\mathrm{FAZ}(\mathrm{P})$ & $\begin{array}{c}\text { Oct/15 } \\
\text { Dec/15 } \\
\text { Feb/16 } \\
\text { Apr/16 } \\
\text { Jun/16 } \\
\text { Aug/16 }\end{array}$ & $\begin{array}{l}20.5 \\
21.6 \\
22.0 \\
18.5 \\
18.5 \\
18.5\end{array}$ & $\begin{array}{l}1.0 \\
1.2 \\
0.3 \\
0.8 \\
0.7 \\
0.9 \\
\end{array}$ & $\begin{array}{c}0.1 \pm 0.0 \\
0.1 \pm 0.0 \\
<0.1 \pm 0.0 \\
0.1 \pm 0.0 \\
0.3 \pm 0.1 \\
0.1 \pm 0.0\end{array}$ & $\begin{array}{c}14.6 \pm 0.0 \\
8.6 \pm 0.0 \\
4.3 \pm 0.0 \\
7.5 \pm 0.0 \\
41.3 \pm 0.2 \\
2.7 \pm 0.0\end{array}$ & $\begin{array}{l}-14.5 \\
-8.5 \\
-4.3 \\
-7.4 \\
-41.0 \\
-2.6\end{array}$ \\
\hline & $\mathrm{BRO}(\mathrm{P})$ & $\begin{array}{c}\text { Oct/15 } \\
\text { Dec/15 } \\
\text { Feb/16 } \\
\text { Apr/16 } \\
\text { Jun/16 } \\
\text { Aug/16 }\end{array}$ & $\begin{array}{l}21.6 \\
21.9 \\
22.0 \\
17.7 \\
17.2 \\
18.4\end{array}$ & $\begin{array}{l}0.4 \\
0.3 \\
0.1 \\
0.4 \\
0.4 \\
0.5\end{array}$ & $\begin{array}{c}0.2 \pm 0.0 \\
0.3 \pm 0.0 \\
<0.1 \pm 0.0 \\
0.1 \pm 0.0 \\
0.2 \pm 0.0 \\
0.6 \pm 0.0\end{array}$ & $\begin{array}{c}12.1 \pm 0.0 \\
14.3 \pm 0.0 \\
5.3 \pm 0.0 \\
10.2 \pm 0.0 \\
11.5 \pm 0.0 \\
17.5 \pm 0.1\end{array}$ & $\begin{array}{c}-11.9 \\
-14.1 \\
-5.3 \\
-10.1 \\
-11.3 \\
-16.9\end{array}$ \\
\hline \multirow[t]{3}{*}{ Impacted sites } & $\mathrm{CAN}(\mathrm{I})$ & $\begin{array}{c}\text { Oct/15 } \\
\text { Dec/15 } \\
\text { Feb/16 } \\
\text { Apr/16 } \\
\text { Jun/16 } \\
\text { Aug/16 }\end{array}$ & $\begin{array}{l}21.2 \\
21.2 \\
20.6 \\
20.7 \\
17.8 \\
17.0\end{array}$ & $\begin{array}{l}0.8 \\
0.5 \\
0.2 \\
0.4 \\
0.2 \\
0.5\end{array}$ & $\begin{array}{c}0.2 \pm 0.0 \\
0.1 \pm 0.0 \\
<0.1 \pm 0.0 \\
0.1 \pm 0.0 \\
<0.1 \pm 0.0 \\
<0.1 \pm 0.0\end{array}$ & $\begin{array}{l}6.8 \pm 0.0 \\
6.3 \pm 0.0 \\
4.1 \pm 0.0 \\
2.7 \pm 0.0 \\
1.9 \pm 0.0 \\
2.0 \pm 0.0\end{array}$ & $\begin{array}{l}-6.6 \\
-6.2 \\
-4.1 \\
-2.6 \\
-1.9 \\
-2.0\end{array}$ \\
\hline & $\mathrm{MIN}(\mathrm{I})$ & $\begin{array}{c}\text { Oct/15 } \\
\text { Dec/15 } \\
\text { Feb/16 } \\
\text { Apr/16 } \\
\text { Jun/16 } \\
\text { Aug/16 }\end{array}$ & $\begin{array}{l}21.8 \\
21.7 \\
22.1 \\
18.9 \\
16.6 \\
18.6\end{array}$ & $\begin{array}{l}0.9 \\
0.4 \\
0.3 \\
0.4 \\
0.6 \\
0.5\end{array}$ & $\begin{array}{l}0.1 \pm 0.0 \\
0.1 \pm 0.0 \\
0.1 \pm 0.0 \\
0.1 \pm 0.0 \\
0.1 \pm 0.0 \\
0.1 \pm 0.0\end{array}$ & $\begin{array}{l}6.6 \pm 0.1 \\
2.1 \pm 0.0 \\
4.4 \pm 0.0 \\
4.4 \pm 0.0 \\
2.5 \pm 0.0 \\
4.6 \pm 0.0\end{array}$ & $\begin{array}{l}-6.5 \\
-2.0 \\
-4.3 \\
-4.3 \\
-2.4 \\
-4.5\end{array}$ \\
\hline & SMA(I) & $\begin{array}{c}\text { Oct/15 } \\
\text { Dec/15 } \\
\text { Feb/16 } \\
\text { Apr/16 } \\
\text { Jun/16 } \\
\text { Aug/16 }\end{array}$ & $\begin{array}{l}24.0 \\
24.4 \\
24.5 \\
20.4 \\
18.5 \\
21.2\end{array}$ & $\begin{array}{l}0.5 \\
0.4 \\
0.6 \\
0.4 \\
0.5 \\
0.6\end{array}$ & $\begin{array}{c}<0.1 \pm 0.0 \\
0.1 \pm 0.0 \\
<0.1 \pm 0.0 \\
0.1 \pm 0.0 \\
<0.1 \pm 0.0 \\
<0.1 \pm 0.0\end{array}$ & $\begin{array}{l}1.7 \pm 0.0 \\
0.6 \pm 0.0 \\
8.2 \pm 0.1 \\
6.8 \pm 0.1 \\
6.9 \pm 0.1 \\
0.8 \pm 0.0\end{array}$ & $\begin{array}{l}-1.7 \\
-0.5 \\
-8.2 \\
-6.7 \\
-6.9 \\
-0.8\end{array}$ \\
\hline
\end{tabular}


al. (2010) studied 72 streams and observed that nitrate and ammonium concentrations were positively related to metabolic rates in US and Puerto Rico. Authors reported that riparian characteristics (e.g., vegetation and soil) and land-use (agriculture and urbanization) influenced in stream nutrient concentrations. In some streams in Indonesia with palm cultivation (Elaeis guineenses), Carlson et al. (2014) reported an increase in ER $\left(5.0 \mathrm{gO}_{2} \mathrm{~m}^{-2} \mathrm{~d}^{-1}\right)$ compared to more preserved areas $\left(2.0 \mathrm{gO}_{2} \mathrm{~m}^{-2} \mathrm{~d}^{-1}\right)$ during dry season. The increase could have been driven by the increasing input of organic matter (e.g., palm leaves). Our data suggest multiple limiting factors of GPP and ER can occur in tropical streams.

Following our initial hypothesis, all streams were heterotrophic with high ER and low GPP, and therefore, especially responsive to increases of organic matter inputs. This study suggests that human activities such as agricultural and land use alter stream ecosystem functioning, as highlighted from the Linear Mixed-Effect models that showed that changes in metabolic rates are explained by the variations in discharge, nutrients and canopy cover. Interestingly, ER was frequently higher in unaltered than altered sites (Tab. 4, maximum of 42.1 and $8.2 \mathrm{gO}_{2} \mathrm{~m}^{-2} \mathrm{~d}^{-1}$, respectively). This suggests that inputs of natural allochthonous organic material in the more pristine sites had a more pronounced effect on ER rates in comparison to organic pollution and nutrient inputs in the impacted study sites. Also, while we just characterized the biofilms in terms of benthic chlorophyll, it is possible that biofilm community structure (e.g., relative importance of algae, bacteria and fungi communities) was significantly different across sites, leading to different respiration rates. The biodiversity and the colonization sequences of different biological communities in the biofilms are subjected to multiple factors and can substantially influence stream metabolism (Artigas et al., 2012; Besemer, 2015).

In order to protect streams in Brazil, it is important to adopt measures to maintain stream ecosystem health. Tromboni and Dodds (2017) pointed out that the implementation of sewage treatment plants as well as phosphate control is lacking and particularly urgent in Brazil, where urban areas are the major driver of nutrient concentration increases in streams, there are no bans on phosphorus-containing detergents, and water treatment is still not common. To mitigate environmental risks, governments in Western Europe and North America (Compton et al., 2011) have enacted legislation to control livestock expansion, fertilizer application, riparian protection, other farm practices, and/or banning phosphate-containing laundry detergents. Such initiatives are still limited in Brazil as well as those for determining nutrient exports across watersheds with varying land uses.

Riparian protection is also important to maintain metabolic rates more similar to the reference natural condition, as highlighted by Silva-Junior (2016). Restoration techniques such as the increase of the hydraulic residence time and reduction of water velocity could increase GPP. With an increase of carbon production, an increase in the complexity of stream food webs could occur. Those changes could modify nutrient retention and exports in addition to restoring ecosystem

Tab. 5. Linear Mixed-Effects models of GPP and ER rates against discharge, velocity, nutrients, depth and canopy cover. $\beta$ is the slope for the variables, $\mathrm{SE}$ is standard error and significant effects at $\mathrm{P}<0.05$. AIC is the Akaike's Information Criterion.

\begin{tabular}{|c|c|c|c|c|c|}
\hline Dependent variable & Independent variable & $\beta$ & SE & P-value & AIC \\
\hline $\operatorname{GPP}\left(\mathrm{gO}_{2} \mathrm{~m}^{-2} \mathrm{~d}^{-1}\right)$ & $\begin{array}{l}\text { Intercept } \\
\text { Discharge } \\
\text { Total phosphorus } \\
\text { Depth }\end{array}$ & $\begin{array}{l}-0.122 \\
-0.050 \\
0.056 \\
0.908\end{array}$ & $\begin{array}{l}0.067 \\
0.013 \\
0.017 \\
0.088\end{array}$ & $\begin{array}{c}* \\
\mathrm{P}<0.05 \\
\mathrm{P}<0.05 \\
\mathrm{P}<0.05\end{array}$ & -75.43 \\
\hline $\operatorname{GPP}\left(\mathrm{gO}_{2} \mathrm{~m}^{-2} \mathrm{~d}^{-1}\right)$ & $\begin{array}{l}\text { Intercept } \\
\text { Velocity } \\
\text { Total phosphorus } \\
\text { Depth }\end{array}$ & $\begin{array}{c}-0.187 \\
-0.623 \\
0.068 \\
0.698\end{array}$ & $\begin{array}{l}0.064 \\
0.187 \\
0.017 \\
0.082\end{array}$ & $\begin{array}{c}* \\
\mathrm{P}<0.05 \\
\mathrm{P}<0.05 \\
\mathrm{P}<0.05\end{array}$ & -77.39 \\
\hline $\mathrm{ER}\left(\mathrm{gO}_{2} \mathrm{~m}^{-2} \mathrm{~d}^{-1}\right)$ & $\begin{array}{l}\text { Intercept } \\
\text { Depth } \\
\text { Discharge } \\
\text { Canopy cover } \\
\text { Soluble reactive phosphorus }\end{array}$ & $\begin{array}{c}-2.043 \\
5.608 \\
-0.240 \\
0.427 \\
0.047\end{array}$ & $\begin{array}{l}1.366 \\
0.712 \\
0.130 \\
0.138 \\
0.161\end{array}$ & $\begin{array}{c}* \\
\mathrm{P}<0.05 \\
0.09 \\
\mathrm{P}<0.05 \\
0.77\end{array}$ & 59.89 \\
\hline $\mathrm{ER}\left(\mathrm{gO}_{2} \mathrm{~m}^{-2} \mathrm{~d}^{-1}\right)$ & $\begin{array}{l}\text { Intercept } \\
\text { Velocity } \\
\text { Total phosphorus } \\
\text { Depth }\end{array}$ & $\begin{array}{c}0.765 \\
-4.159 \\
0.297 \\
3.931\end{array}$ & $\begin{array}{l}0.571 \\
1.745 \\
0.154 \\
0.759\end{array}$ & $\begin{array}{c}* \\
\mathrm{P}<0.05 \\
0.06 \\
\mathrm{P}<0.05\end{array}$ & 60.74 \\
\hline
\end{tabular}

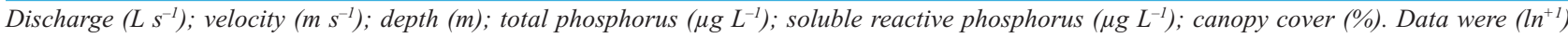
transformed; " not calculated. 
services (Palmer et al., 2014). Understanding stream ecosystem function can provide insights of the effects of the reduction of vegetation by the changes of the Native Vegetation Protection Law of Brazil ("Brazilian Forest Code") that recently reduced the width of the zone of protected riparian vegetation.

The results of this study are important because they provide reference metabolism characteristics of streams located in the understudied tropical Cerrado and information regarding its relation to biological and physico-chemical aspects. Such information is fundamental for classifying and modelling metabolic rates of lotic aquatic systems as well as guiding management and restoration efforts (Bernhardt et al., 2018). Metabolism can be used as a functional indicator of stream health and anthropogenic impacts (Fellows et al., 2006). The estimation of the metabolism over the years can indicate how drivers such as light availability, allochthonous inputs, and temperature have changed and are likely to change the metabolism (Bernhardt et al., 2018). The use of functional indicators based on functional ecosystem processes has some advantages over structural ones because they encompass a wider variety of physical and biological factors across different habitats (Young et al., 2008; Gucker et al., 2009) allowing for comparisons among streams in different areas (Davies and Jackson, 2006).

\section{CONCLUSIONS}

The tropical streams we studied were influenced by the degree of human modification in their watersheds in relation to different environmental impacts (e.g., agricultural crops, urban areas, soil erosion/loss and fragmentation of riparian vegetation). The streams were net heterotrophic throughout the whole analyzed period, with respiration rates (maximum of $42.1 \mathrm{gO}_{2} \mathrm{~m}^{-2} \mathrm{~d}^{-1}$ ) higher than usually reported in most studies available in the literature, and low rates of gross primary production. Land use was not directly related to metabolic rates. Such rates usually present a natural day-to-day variability that can be not captured by limited measurements across different land uses. The light attenuation by the riparian vegetation was one of the most important predictors of the metabolic rates due to its role in restricting solar radiation availability by the shading effect. Also, discharge explained some variation on GPP, probably due to its effect on the reduction of biomass of primary producers by the abrasion caused by water velocity and turbulence, whose effect was probably greater in the rainy summer period in the studied streams. Metabolism has been used as a functional indicator of the level of disturbance and sensitivity to anthropogenic impacts in streams. Our study indicates that tropical streams can be vulnerable to deforestation, discharge alteration related to flow shifts under global climate changes, and alteration of organic matter loading leading to further dissolved oxygen consumption. Such influences at the base of the food web could have implications for ecosystem functioning and stream food webs.

\section{ACKNOWLEDGMENTS}

We thank CAPES (Coordenação de Aperfeiçoamento de Pessoal em Ensino Superior), under the program "Science Without Borders" for the financial support (Process Number 88881.068045/ 2014-01) to W.K. Dodds as a visiting researcher in Brazil and to V. Neres-Lima (88887.091574/2014-00), and FAPESP (Fundação de Amparo à Pesquisa do Estado de São Paulo) for the financial support to D.G.F. Cunha (Process Number 2016/14176-1). W.A. Saltarelli thanks CNPq (Conselho Nacional de Desenvolvimento Científico e Tecnológico) and F. Tromboni thanks CAPES/FAPERJ (Process Number E-26/100.018/2015) for the scholarships. We also thank the two anonymous reviewers for their helpful comments to improve our paper.

\section{REFERENCES}

Acuña V, Giorgi A, Muñoz I, Uehlinger U, Sabater S, 2004. Flow extremes and benthic organic matter shape the metabolism of a headwater Mediterranean stream. Freshwater Biol. 49:960-971.

APHA, 2012. Standard methods for the examination of water and wastewater. American Water Works Association, Washington.

Aristi I, von Schiller D, Arroita M, Barceló D, Ponsatí L, GarcíaGalán MJ, Sabater S, Elosegi A, Acuña V, 2015. Mixed effects of effluents from a wastewater treatment plant on river ecosystem metabolism: subsidy or stress? Freshwater Biol. 60:1398-1410.

Artigas J, Fund K, Kirchen S, Morin S, Obst U, Romaní AM, Sabater S, Schwartz T, 2012. Patterns of biofilm formation in two streams from different bioclimatics regions: analysis of microbial community structure and metabolism. Hydrobiology 695:83-96.

Bates D, Maechler M, Bolker B, Walker S, 2014. Fitting Linear Mixed-Effects Models Using Lme4. ArXiv 1406.5823 (June): 1-51. http://arxiv.org/abs/1406.5823.

Battin TJ, Kaplan LA, Newbold JD, Cheng X, Hansen C, 2003. Effects of Current Velocity on the Nascent Architecture of Stream Microbial Biofilms. Appl. Environ. Microbiol. 69:5443-5452.

Benson A, Zane M, Becker T, Visser A, Uriostegui S, De Rubeis E, Moran J, Esser B, Clark J, 2014. Quantifying reaeration rates in alpine streams using deliberate gas tracer experiments. Water 6:1013.

Bernhardt ES, Heffernan JB, Grimm NB, Stanley EH, Harvey JW, Arroita M, Appling AP, Cohen MJ, McDowell WH, Hall 
RO, Read JS, Roberts BJ, Stets EG, Yackulic CB, 2018. The metabolic regimes of flowing waters. Limnol. Oceanogr. 63:s99-s118.

Bernot MJ, Sobota DJ, Hall RO, Mulholland PJ, Dodds WK, Webster JR, Tank JL, Ashkenas LR, Cooper LW, Dahm CN, Gregory SV, Grimm NB, et al., 2010. Inter-regional comparison of land-use effects on stream metabolism. Freshwater Biol. 55:1874-1890.

Besemer K, 2015. Biodiversity, community structure and function of biofilms in stream ecosystems. Res. Microbiol. 166:774-781.

Bleich ME, Piedade MTF, Mortati AF, André T, 2015. Autochthonous primary production in southern Amazon headwater streams: Novel indicators of altered environmental integrity. Ecol. Indic. 53:154-161.

Boëchat IG, Krüger A, Giani A, Figueredo CC, Gücker B, 2011. Agricultural land-use affects the nutritional quality of stream microbial communities. FEMS Microbiol. Ecol. 77:568-576.

Bott TL, 2006. Primary productivity and community respiration, p. 663-690. In: F.R. Hauer and G. Lamberti (eds.), Methods in stream ecology. Elsevier, Amsterdam.

Bott TL, Montgomery DS, Newbold JD, Arscott DB, Dow CL, Aufdenkampe AK, Jackson JK, Kaplan L a., 2006. Ecosystem metabolism in streams of the Catskill Mountains (Delaware and Hudson River watersheds) and Lower Hudson Valley. J. N. Am. Benthol. Soc. 25:1018-1044.

Boulton AJ, Boyero L, Covich AP, Dobson M, Lake S, Pearson R, 2008. Are tropical streams ecologically different from temperate streams?, p. 257-284 In: D. Dudgeon (ed.), Tropical stream ecology. Academic Press, San Diego.

Bunn SE, Davies PM, Mosisch TD, 1999. Ecosystem measures of river health and their response to riparian and catchment degradation. Freshwater Biol. 41:333-345.

Burrell TK, O'Brien JM, Graham E, Simon KS, Harding JS, McIntosh AR, 2014. Riparian shading mitigates stream eutrophication in agricultural catchments. Freshw. Sci. 33:73-84.

Canale RP, Owens EM, Auer MT, Effler SW, 1995. Validation of water-quality model for Seneca River, N.Y. J. Water Resour. Plan. Manag. 121:241-250.

Capps KA, Bentsen CN, Ramírez A, 2016. Poverty, urbanization, and environmental degradation: urban streams in the developing world. Freshw. Sci. 35:429-435.

Carlson KM, Curran LM, Ponette-González AG, Ratnasari D, Ruspita, Lisnawati N, Purwanto Y, Brauman KA, Raymond PA, 2014. Influence of watershed-climate interactions on stream temperature, sediment yield, and metabolism along a land use intensity gradient in Indonesian Borneo. J. Geophys. Res. Biogeosci. 119:1110-1128.

Casas JJ, Larrañaga A, Menéndez M, Pozo J, Basaguren A, Martínez A, Pérez J, González JM, Mollá S, Casado C, Descals E, Roblas N, et al., 2013. Leaf litter decomposition of native and introduced tree species of contrasting quality in headwater streams: How does the regional setting matter? Sci. Total Environ. 458-460:197-208.

Compton JE, Harrison JA, Dennis RL, Greaver TL, Hill BH, Jordan SJ, Walker H, Campbell H V., 2011. Ecosystem services altered by human changes in the nitrogen cycle: a new perspective for US decision making. Ecol. Lett. 14:804-815.

Correa-González JC, Chávez-Parga MC, Cortés JA, Pérez-
Munguía RM, 2014. Photosynthesis, respiration and reaeration in a stream with complex dissolved oxygen pattern and temperature dependence. Ecol. Modell. 273:220-227.

Dai A, Trenberth KE, 2002. Estimates of freshwater discharge from continents: Latitudinal and seasonal variations. J. Hydrometeorol. 3:660-687.

Davies SP, Jackson SK, 2006. The biological condition gradient: a descriptive model for interpreting change in aquatic ecosystems. Ecol. Appl. 16:1251-66.

Dodds WK, 2007. Trophic state, eutrophication and nutrient criteria in streams. Trends Ecol. Evol. 22:669-676.

Dodds WK, Cole JJ, 2007. Expanding the concept of trophic state in aquatic ecosystems: It's not just the autotrophs. Aquat. Sci. 69:427-439.

Dodds WK, Gido K, Whiles MR, Daniels MD, 2015. The stream biome gradient concept : factors controlling lotic systems across broad biogeographic scales. Freshw. Sci. 34:1-19.

Dodds WK, Perkin JS, Gerken JE, 2013. Human impact on freshwater ecosystem services: A global perspective. Environ. Sci. Technol. 47:9061-9068.

Dodds WK, Tromboni F, Saltarelli WA, Cunha DGF, 2017. The root of the problem: Direct influence of riparian vegetation on estimation of stream ecosystem metabolic rates. Limnol. Oceanogr. Lett. 2:9-17.

Fellows CS, Clapcott JE, Udy JW, Bunn SE, Harch BD, Smith MJ, Davies PM, 2006. Benthic metabolism as an indicator of stream ecosystem health. Hydrobiologia 572:71-87.

Finn DS, Bonada N, Múrria C, Hughes JM, 2011. Small but mighty: headwaters are vital to stream network biodiversity at two levels of organization. J. N. Am. Benthol. Soc. 30:963-980.

Foley JA, 2005. Global consequences of land use. Science 309:570-574.

Gessner MO, Swan CM, Dang CK, McKie BG, Bardgett RD, Wall DH, Hättenschwiler S, 2010. Diversity meets decomposition. Trends Ecol. Evol. 25:372-380.

Grace MR, Giling DP, Hladyz S, Caron V, Thompson RM, Nally R Mac, 2015. Fast processing of diel oxygen curves: Estimating stream metabolism with BASE (BAyesian Single-station Estimation). Limnol. Oceanogr. 13:103-114.

Gücker B, Boëchat IG, Giani A, 2009. Impacts of agricultural land use on ecosystem structure and whole-stream metabolism of tropical Cerrado streams. Freshwater Biol. 54:2069-2085.

Gücker B, Pusch MT, 2006. Regulation of nutrient uptake in eutrophic lowland streams. Limnol. Oceanogr. 51:1443-1453.

Hall RO, Beaulieu JJ, 2013. Estimating autotrophic respiration in streams using daily metabolism data. Freshw. Sci. 32:507-16.

Hall RO, Tank JL, 2003. Ecosystem metabolism controls nitrogen uptake in streams in Grand Teton National Park, Wyoming. Limnol. Oceanogr. 48:1120-1128.

Hall RO, 2016. Metabolism of streams and rivers: Estimation, controls, and application, p. 151-180. In: J.B. Jones and E. Stanley (eds.), Stream ecosystems in a changing environment. Academic Press, San Diego.

Hall RO, Yackulic CB, Kennedy TA, Yard MD, Rosi-Marshall EJ, Voichick N, Behn KE, 2015. Turbidity, light, temperature, and hydropeaking control primary productivity in the Colorado River, Grand Canyon. Limnol. Oceanogr. 60:512-526. 
Halliday SJ, Skeffington RA, Wade AJ, Bowes MJ, Gozzard E, Newman JR, Loewenthal M, Palmer-Felgate EJ, Jarvie HP, 2015. High-frequency water quality monitoring in an urban catchment: hydrochemical dynamics, primary production and implications for the Water Framework Directive. Hydrol. Process. 29:3388-3407.

Izagirre O, Agirre U, Bermejo M, Pozo J, Elosegi A, 2008. Environmental controls of whole-stream metabolism identified from continuous monitoring of Basque streams. J. N. Am. Benthol. Soc. 27:252-268.

Jackson MC, Loewen CJG, Vinebrooke RD, Chimimba CT, 2016. Net effects of multiple stressors in freshwater ecosystems: a meta-analysis. Global Change Biol. 22:180-189.

Kuznetsova A, Brockhott P, Christensen RHB, 2016. lmerTest: Tests in Linear Mixed Effects Models. R package version 2.0-29.

Lemmon PE, 1956. A spherical densiometer for estimating forest overstory density. Forest Sci. 2:314-320.

Lewis WM, 2008. Physical and chemical features of tropical flowing waters, p. 1-21. In: D. Dudgeon (ed.), Tropical stream ecology. Academic Press, San Diego.

Loiselle SA, Gasparini Fernandes Cunha D, Shupe S, Valiente E, Rocha L, Heasley E, Belmont PP, Baruch A, 2016. Micro and Macroscale Drivers of Nutrient Concentrations in Urban Streams in South, Central and North America. PLoS One 11:e0162684.

Longhi D, Bartoli M, Nizzoli D, Laini A, Viaroli P, 2016. Do oxicanoxic transitions constrain organic matter mineralization in eutrophic freshwater wetlands? Hydrobiologia 774:81-92.

Marzolf ER, Mulholland PJ, Steinman AD, 1994. Improvements to the diurnal upstream-downstream dissolved oxygen change technique for determining wholestream metabolism in small streams. Can. J. Fish. Aquat. Sci. 51:1591-1599.

Merseburger G, Martí E, Sabater F, Ortiz JD, 2011. Point-source effects on $\mathrm{N}$ and $\mathrm{P}$ uptake in a forested and an agricultural Mediterranean streams. Sci. Total Environ. 409:957-967.

Meyer JL, Paul MJ, Taulbee WK, 2005. Stream ecosystem function in urbanizing landscapes. J. N. Am. Benthol. Soc. 24:602-612.

Meyer JL, Strayer DL, Wallace JB, Eggert SL, Helfman GS, Leonard NE, 2007. The contribution of headwater streams to biodiversity in river networks1. J. Am. Water Resour. Assoc. 43:86-103.

Mora C, Frazier AG, Longman RJ, Dacks RS, Walton MM, Tong EJ, Sanchez JJ, Kaiser LR, Stender YO, Anderson JM, Ambrosino CM, Fernandez-Silva I, Giuseffi LM, Giambelluca TW, 2013. The projected timing of climate departure from recent variability. Nature 502:183-187.

Mulholland PJ, Fellows CS, Tank JL, Grimm NB, Webster JR, Hamilton SK, Marti E, Ashkenas L, Bowden WB, Dodds WK, Mcdowell WH, Paul MJ, Peterson BJ, 2001. Interbiome comparison of factors controlling stream metabolism. Freshwater Biol. 46:1503-1517.

Mulholland PJ, Houser JN, Maloney KO, 2005. Stream diurnal dissolved oxygen profiles as indicators of in-stream metabolism and disturbance effects: Fort Benning as a case study. Ecol. Indic. 5:243-252.

Neres-Lima V, Machado-Silva F, Baptista DF, Oliveira RBS, Andrade PM, Oliveira AF, Sasada-Sato CY, Silva-Junior
EF, Feijó-Lima R, Angelini R, Camargo PB, Moulton TP, 2017. Allochthonous and autochthonous carbon flows in food webs of tropical forest streams. Freshwater Biol. 62:1012-1023.

Odum HT, 1956. Primary production in flowing waters. Limnol. Oceanogr. 1:102-117.

Palmer MA, Filoso S, Fanelli RM, 2014. From ecosystems to ecosystem services: Stream restoration as ecological engineering. Ecol. Eng. 65:62-70.

Pinardi M, Bartoli M, Longhi D, Viaroli P, 2011. Net autotrophy in a fluvial lake: the relative role of phytoplankton and floating-leaved macrophytes. Aquat. Sci. 73:389-403.

Pinardi M, Rossetto M, Viaroli P, Bartoli M, 2014. Daily and seasonal variability of $\mathrm{CO}_{2}$ saturation and evasion in a free flowing and in a dammed river reach. J. Limnol. 73:468481. DOI: https://doi.org/10.4081/jlimnol.2014.947

R Core Team, 2015. R: A language and environment for statistical computing. Foundation for Statistical Computing, Vienna, Austria. http://www.R-project.org/

Rasmussen JJ, McKnight US, Loinaz MC, Thomsen NI, Olsson ME, Bjerg PL, Binning PJ, Kronvang B, 2013. A catchment scale evaluation of multiple stressor effects in headwater streams. Sci. Total Environ. 442:420-431.

Roley SS, Tank JL, Griffiths NA, Hall Jr. RO, Davis RT, 2014. The influence of floodplain restoration on whole-stream metabolism in an agricultural stream: insights from a 5-year continuous data set. Freshw. Sci. 33:1043-1059.

Saltarelli WA, 2017. [Metabolismo em riachos subtropicais: variação espaço-temporal e influência de um gradiente de condições ambientais].[Master Thesis in Portuguese]. Universidade de São Paulo.

Sartory DP, Grobbelaar JU, 1984. Extraction of chlorophyll a from freshwater phytoplankton for spectrophotometric analysis. Hydrobiologia 114:177-187.

Silva-Junior EF, 2016. Land use effects and stream metabolic rates: a review of ecosystem response. Acta Limnol. Bras. 28:e10.

Sobota DJ, Johnson SL, Gregory S V, Ashkenas LR, 2012. A stable isotope tracer study of the influences of adjacent land use and riparian condition on fates of nitrate in streams. Ecosystems 15:1-17.

Taniwaki RH, Piggott JJ, Ferraz SFB, Matthaei CD, 2017. Climate change and multiple stressors in small tropical streams. Hydrobiologia 793:41-53.

Tank JL, Rosi-Marshall EJ, Griffiths NA, Entrekin SA, Stephen ML, 2010. A review of allochthonous organic matter dynamics and metabolism in streams. J. N. Am. Benthol. Soc. 29:118-146.

Tromboni F, Dodds WK, 2017. Relationships between land use and stream nutrient concentrations in a highly urbanized tropical region of Brazil: Thresholds and riparian zones. Environ. Manage. 60:30-40.

Tromboni F, Dodds WK, Neres-Lima V, Zandonà E, Moulton TP, 2017. Heterogeneity and scaling of photosynthesis, respiration, and nitrogen uptake in three Atlantic Rainforest streams. Ecosphere 8:e01959.

Uehlinger U, Kawecka B, Robinson CT, 2003. Effects of experimental floods on periphyton and stream metabolism below a high dam in the Swiss Alps (River Spöl). Aquat. Sci. 65:199-209. 
Webster RJ, Valett HM, 2006. Solute dynamics, p. 169-185. In: F.R. Hauer and G.A. Lamberti (eds.), Methods in stream ecology. Academic Press, San Diego.

White AF, Blum AE, Schulz MS, Vivit D V., Stonestrom DA, Larsen M, Murphy SF, Eberl D, 1998. Chemical weathering in a tropical watershed, Luquillo Mountains, Puerto Rico: I. Long-term versus short-term weathering fluxes. Geochim. Cosmochim. Acta 62:209-226.

Young RG, Huryn AD, 1996. Interannual variation in discharge controls ecosystem metabolism along a grassland river continuum. Can. J. Fish. Aquat. Sci. 53:2199-2211.

Young RG, Huryn AD, 1999. Effects of land use on stream metabolism and organic matter turnover. Ecol. Appl. 9:13591376.

Young RG, Matthaei CD, Townsend CR, 2008. Organic matter breakdown and ecosystem metabolism: functional indicators for assessing river ecosystem health. J. N. Am. Benthol. Soc. 27:605-625. 